\title{
The Role of Reflective Practitioner Heuristic Inquiry in Institutional learning and Research
}

\author{
Edward Wong Sek Khin \\ Choong Kwai Fatt \\ Faculty of Business \& Accountancy \\ University of Malaya, Malaysia \\ E-mail: edwardwong@graduate.uwa.edu.au
}

\begin{abstract}
In this paper, the authors reports on a critical and reflective practitioner heuristic inquiry that investigates a case study concern a post-modern approach in enhancing institutional teaching and research involving adult learning. In addition, the authors investigate the research process itself and their own professional academic practices. Of particular interest is that this paper offers practitioners and teachers a new way of thinking about and pursuing concerns about a foray into many different disciplines, among these are sociology, education, business, strategic decision making, knowledge management, organisational theory, and current critical schools of thought, such as the work of Michel Foucault. The paper aims to bring out inner dialogues and open discourse responses in one-on-one interviews within a phenomenological, reflective practitioner methodology. The authors seek to explain why these roles are experiencing increased interest in the nature of critical institutional research. This approach assumes that any learning situation has the potential to yield new ideas for enhancing the researcher's learning, provided we do the kinds of thinking that opens up new possibilities. That is, the researcher offers an account of this innovative thinking, suggesting a framework of questions, which practitioners can use, and then drawing upon their existing knowledge in order to generate new insights and possibilities for practice. One area of controversy between critical institutional research and the traditional research is the role of "reflective practice," which remains under-developed. In this paper is explored the importance of reflective practice employing the term "living thesis paradigm" as a means of developing expert research methods.
\end{abstract}

Keywords: Reflective Practice, Action Research, Cognitive learning, Institutional research development 


\section{Introduction}

The main aim of this paper is to examine the role of employing the reflective professional practice action research approach in evaluating the explication of tacit knowledge. The paper presents an account of the author's personal experiences, a personal story of his development as a heuristically critical reflective practitioner, both as a knowledge management consultant in business and then as an academic teacher and researcher. In order to examine the author's development, he felt it necessary to search into his past so that he can account for his values and actions in the present.

The paper also discusses the role of developing reflective skills and processes employed in conducting critical Institutional Professional Research (IPR). In recent years, there has been an increase interest in the nature of critical IPR research and the development of methodologies to explore this subject. One area of controversy between critical IPR research and the traditional IPR research is the role of "reflective practice," which remains under-developed. In this paper is explored the importance of reflective practice employing the term "living thesis paradigm" as a means of developing expert research methods.

The first section of this paper introduces the literature of reflective practice, which defines what constitutes a reflective practitioner; some philosophical dimensions involved in the development of the living thesis paradigm and then describes and justifies the author's writing style. The second section provides the discussion of the research methodology. The third section discusses a focus group case study of doctoral candidates employing the living thesis paradigm of reflective practice in investigating the explication of tacit knowledge while the last section identifies areas for future research.

\section{Literature Review}

\subsection{What Is A Reflective Practitioner?}

Schön (1984) and Moon (2000) describes that the reflective practitioner as someone who is simply thoughtful about his or her own practice. In fact, reflective practice involves the mental process of reflecting, which may or may not be characterised by what we have called "being reflective.” For example, these authors speak of the reflective practitioner as a person with a self-image as a facilitator, for whom there is important recognition of the uncertainty within the profession, as one who has the knowledge base of a member of his/her profession, and is aware of the problems that need to be resolved in a professional practice. The reflective practitioner copes with this uncertainty by putting the relationship with their clients at the centre of his/her professional practice with an attempt to develop reflectively negotiated shared meanings and understandings as a joint process.

Proctor (1993) takes a similar view, stating that reflective practice is the process of looking back in a critical way at what has occurred and then using the results of this process, together with professional knowledge (with technical and ethical aspects), to tackle new situations. Some critical elements have been widely associated with reflective practice and they are often taken to be the main purpose of reflection (Smyth, 1989). In similar vein to Smyth's ideology, Wong and Williams (2002) state that in a reflective professional education, the activities of 
teaching often need to be set in their historical, political, theoretical, and moral context as not considering them turns reflective teaching into a technical process. Reflection is the "active and militant" tool that enables that contextualisation (Smyth, 1989). In this regard, the "technical-rational" education fails to provide the elements necessary to enable the doctoral students to develop the heuristics needed to deal with the unpredictability and chaos of real world issues.

According to Wong and Williams (2002), professional practice action research and reflective practitioner research and typically written in distinctive reflective practitioner styles, as individuals evolving as the action researchers find their own voice and distinctive authorial style. This evolution occurred in the writing style used by Donald Schön from 1983 (Schön, 1983 and 1987). Dewey (1933) who wrote about the function of reflective thought in learning from experience first alluded to this concept of reflective practice. He further indicates that the researcher's notes and reflections and insights are integrated with the empirical data from interviews with colleagues, supervisors, mentors, and clients is usually analysed using reflective practitioner methodology as identified by Schön (1983), with additional ideas gained from Overmeer et al (1998). This research method allows the researcher to give an account of how they applied knowledge in their workplaces. It encourages them to reflect on their experiences and then to comment on what they believed they had learned from those experiences (Wong and Williams, 2002; Williams, 2000, 2001).

\subsection{Creating The Living Thesis Paradigm: The Espistemological Perspective}

The author notes the developments in what Jack Whitehead terms the "living thesis paradigm" (1993, p 69) at the Perth Centre of Reflective Practitioner Research Group (Wong and Williams, 2002) and at the University of Bath's Centre for Action Research Professional Practice (Whitehead 1998, 2002; Reason 1999). Whitehead argues that these dialogues are a new way in which action researchers represent the living aspect of their theories about practice and that this approach celebrates a living form of practitioner educational theory, which is open-ended and contains an intention to create something better (Wong, 2003). Whitehead (1998) asserts that including the "I" and embracing subjectivity is essential to research within this paradigm. Furthermore, Whitehead (2002) exhorts individuals to not be silent, or hold back their perspective or try to struggle dishonestly in order to fit their private world with their public face through the process of denying or by inauthentically conforming to oppressive domination concerning gender, race, or differently cultured selves.

The living thesis paradigm compels the author to document any conflicts he or she experiences, especially when the values he or she holds internally are not reflected in the way he or she behaves externally, and the satisfaction he or she feels when their values and actions are in harmony. Put in different words, Whitehead's $(1993,1996)$ comments that one's espoused theory ideally should be consistent with one's lived theory. Whitehead further argues that living theory refers to the explanations not embodied in the individual's life forces, but it contains an intention to create something in the future based on that person's goals or values and controlled within an action plan. Hence, this theory is an explanation, which makes sense 
of the present in terms of an evaluation of the past with an intention to change some aspect of one's own practice, or the world in the future (Wong, 2003).

\section{Research Methodology}

This study involves research, teaching, and learning contexts in higher education with human science hermeneutical dimensions (i.e. the process of mimetics through reconstructions of facts by the understanding of its meanings and intentions rather than by deductive explanation (Standing, 2000; Wong, 2003)), it is that an ethnographic reflection on professional practitioner focus group case study methodology is most appropriate. The author studied one focus group in-depth, the doctoral candidates at University \#B, an Australian University, in an attempt to gain empirical and interpretive understanding of their results, that is, in terms of the conversion of tacit knowledge to explicit knowledge, by their adoption of the Culture Management Processes in higher education.

\section{Research Objectives}

In summary, the literature review above has attempted to provide an overview of the ontological and epistemological context pertaining to action and reflective practitioner research. The aim of this research is to develop a model of explicating tacit knowledge by employing ethnographic research methodology. Under this approach, the researcher should be a member of the work group or culture that is under research. Thus, the researcher's responses, thoughts, and experiences are important and should be included in the empirical data and analysis. From this, the researcher can glean warranted assertions from his or her own lived experience as well as from others' experience.

\section{Discussion of Case Scenario}

University \#B is an Australian university. University \#B is one of the main universities in Australia and has a total of 15000 students. University \#B offers a broad range of degree programmes from undergraduate to doctoral studies.

\subsection{Analysis Framework: A Case Study Of An Australian University}

In this study, the dialectic hermeneutic approach was used to interpret the data (Yin 1994). The source of the research methodology used for this particular study was a case study within an interpretative approach.

According to Boland (1991, p. 439), "Hermeneutics is the study of interpretation, especially the process of coming to understand a text. Hermeneutics emerged as a concern with interpreting ancient religious texts and has evolved to address the general problem of "How we give meaning to what is unfamiliar and alien" (p. 440). In short, it is concerned with the meaning of a text or text analogue. The data in this study, (the interview transcripts and reflective practitioner data), were analysed in terms of themes, motifs and key words.

In collecting the data from University B's doctoral team member, key players were identified from University B's and six doctoral candidates acted as cultural brokers interviewed. The interviews were semi-structured and later transcribed. Each interview took two hours to 
complete and focused on the objectives of the particular area of cultural knowledge that the individual was involved. In addition, the networks, which were shaping the diffusion, design, and implementation processes, were scrutinised. In addition, informal conversations and documentary evidence were used in order to obtain rich process descriptions of the project (Sekaran, 1992, Yin, 1994).

This case study explores the relationship between the analysis framework of the Hofstede (1991) and Gannon (1994) Regional Development Cultural Framework model.

A summary of the data sources used to answer the research questions -

Table.1. Data Sources to answer the research questions

\begin{tabular}{|c|c|}
\hline & Method \\
\hline $\begin{array}{l}\text { 1. To what extent can you explain the interaction of the environment and } \\
\text { the human habitation of both Australia and Indonesia and the internal and } \\
\text { external forces that shaped these places into the countries they are now? } \\
\text { In addition, how these interactions will reflect cultural values and sources } \\
\text { of reactive forces that defend, protect, and expand these cultures. }\end{array}$ & $\begin{array}{l}\text { Semi-structured interview with the } \\
\text { regional co-ordinator, } \\
\text { Observation during activity time, } \\
\text { Fieldnotes. }\end{array}$ \\
\hline $\begin{array}{l}\text { 2. Who and what are the Indonesians? What holds such a diverse place } \\
\text { together and what are the interactions among so many diverse groups? } \\
\text { In other words, what are the patterns of humanity over such a widely } \\
\text { dispersed chain of islands? This is the source of geographical study of } \\
\text { this place, which is also the definition of geography. }\end{array}$ & $\begin{array}{l}\text { Semi-structured interview with } \\
\text { administration officer No 1, } \\
\text { Observation during activity time, } \\
\text { Fieldnotes. }\end{array}$ \\
\hline $\begin{array}{l}\text { 3. How do you regard as an explanation, that historical cultural and } \\
\text { political perceptions are generated and not innate to a particular society } \\
\text { and that these subjective perceptions evolve from both vicarious and real } \\
\text { experiences? The sources of vicarious perceptions are through the } \\
\text { media, and that the control of the media can determine and generate } \\
\text { certain subjective perceptions but not objective cognition, which requires } \\
\text { examination and thoughtful consideration to reach a logical set of at least } \\
\text { a small set of warranted conclusions? }\end{array}$ & $\begin{array}{l}\text { Semi-structured interview with } \\
\text { field officer No 1, } \\
\text { Observation during activity time, } \\
\text { Fieldnotes. }\end{array}$ \\
\hline $\begin{array}{l}\text { 4. Consider the game of Chinese Whispers game; do you think that the } \\
\text { conclusion of the game is perhaps more of a cultural significance than a } \\
\text { political one? The nature or nurture argument arises as we attempt to } \\
\text { explain and perhaps categorise the sources of these events. Here, let us } \\
\text { assume that humans we consider to be 'normal,' to be exactly that. } \\
\text { What they become as adults is a total of their lifetime's experiences and } \\
\text { these experiences are founded upon the five senses and a cognitive effort } \\
\text { to make these into a self-explanatory and leading to, perhaps, a logical } \\
\text { life's tale. In addition, we have the social experiences that determine the } \\
\text { product. The inputs into a person's nurture are complex and beyond the } \\
\text { scope of this work, but if we can assume that experiences are at first } \\
\text { sensory and then are processed with cognitive effort then we can assume } \\
\text { that what makes an Australian 'Australian' and an Indonesian } \\
\text { 'Indonesian,' are local and localised processes. }\end{array}$ & $\begin{array}{l}\text { Semi-structured interview with } \\
\text { administration officer No 2, } \\
\text { Observation during activity time, } \\
\text { Fieldnotes. }\end{array}$ \\
\hline $\begin{array}{l}\text { 5. What do you think of the wisdom of the saying 'believe nothing you } \\
\text { read, little of what you see, and less of what you hear' is applicable to the } \\
\text { situation found in all societies? }\end{array}$ & $\begin{array}{l}\text { Semi-structured interview with } \\
\text { field officer No 2, } \\
\text { Observation during activity time, } \\
\text { Fieldnotes. }\end{array}$ \\
\hline
\end{tabular}




\subsection{Analysing the data}

The process of the investigation began with a semi-structured interview with the six participants. In the course of these interviews, the author was able to establish a rapport with the participants (Goffman, 1971, p. 365). The author was also able to collect some background information regarding their perceptions, beliefs, and awareness of what constitutes effective Culture Management through the adoption of an Information Management Systems, as well as establishing a rapport with the participants

\subsection{Reliability and validity}

Burns (1994) claims that a researcher can employ triangulation techniques to ascertain reliability and validity in case study research. Triangulation in information systems research involves the use of two or more data-collection methods to check for consistency of the emerging findings. This helps prevent the researcher from accepting too readily the validity of the initial findings. Thus, to ensure reliability and validity of this study, the author used the following data collection methods: 1) non-participant observations, (2) semi-structured interview with the 6 participants, and 3) specific reflections by the six participants.

\subsection{Methodology limitations}

As with any research, there were methodology limitations: in this case, these included:

1. Restrictions of qualitative research,

2. Availability of interviewees,

3 Numbers involved in the case study, including both sample size and selection procedures.

\subsection{Limitations of qualitative research}

Unlike quantitative research, which has a strict set of procedures for each technique used, the nature of qualitative research allows for a greater flexibility of the interpretation of the results (Denzin \& Lincoln, 1994; Copper, 1999, p. 2). This flexibility means that there is a lack of comparability between interviews because of the lack of standardisation (Sampson, 1996, p. 331). The lack of standardisation in interview outcome that results from this study requires that the researcher to draw intelligent conclusions from the general view presented by those interviewed.

\subsection{Limitations of availability of interviewees}

The busy schedules of essential players in the participating organisations inevitably placed time limits on interviews. At times, responses to questions asked were rushed. The author made follow up calls to minimise these drawbacks, and to clarify uncertain areas and probe questionnaire issues further.

\section{Results and Discussion}

\subsection{Analysis based upon Action Research criteria list}


In this section, the author described and analysed the case study regarding six doctoral candidates from University B in dealing with the perceptions linking Australia to Indonesia and Indonesia to Australia. The links drawn to commonalities in theories of cultural taxanomy, is not a problem with a secular state such as Australia, it is only when religious differences in an unstable political situation that creates serious and perhaps unsolvable problems. From this situation, to answer the research question in this chapter, the author shall present the insights that can be gained from a post-modern inspired approach in identifying and establishing why Indonesian and Australia were at particular times acrimonious, researched by using a largely interpretivist approach.

\section{Conclusion}

The authors exposed the development of his "living thesis paradigm" theory (Whitehead, 2002) through a multi-voice dialogue about the life-world of his focus group of doctoral candidates from University \#B. Firstly, as a journeying practitioner researcher the author describe his "big picture" view of managing organisational tacit knowledge through the adoption of Knowledge Management Process Systems.

In the methodology section, the authors translate and interpret the transcripts of his participants. Secondly, in the reflexive practitioner's perspective the author describes his development journey towards the evaluative criteria for judging the merit of the research by addressing his understanding of knowledge management and compares it with the literature. The author then highlights the dilemma the author faced in translating theory into practice, and then relates it to the organisational knowledge sharing culture. Thirdly, in the action-researcher's perspective the author discusses the influence of the philosophical framework with the provision of other authenticating point of views. These three viewpoints relate the research outcomes from the thoughts and reflections from a personal life-world to the broader setting of the practitioner's world (Wong, 2004).

Through this action-researcher perspective, the author has come to understand the local situation by thinking reflexively, analysing evidence, and writing his story of this inquiry (Richardson, 1994, p. 518).

\subsection{Limitations of the study}

The limitations of this workshop study pertain to the information gathered through the limited interviews. The veracity of the data gathered rests solely on the integrity and knowledge of the interviewed participants.

\section{$\underline{\text { Future research }}$}

The following issue may be worthy of further investigation:

To what extent are the skills and processes of reflective practice, if taught at the undergraduate level, transferable to the post-graduate stage and early professional life? 


\section{References}

Denzin, N. K., and Lincoln, Y.S. (Eds.). (1994). Handbook of qualitative research. California: Sage Publication. pp143-281

Lyotard, F. (1986) The Postmodern Condition: A Report on Knowledge. Manchester: Manchester University Press, pp 108-167

Moon, J. (2000). Reflection in Learning and Professional Development. London: Kogan Page Press.

Morgan, D. L. (1998). Focus Groups as Qualitative Research. Newbury Park: Sage Publications.

Ngwenyama, K. O., and Lee. A. S. (1997a). Communication richness in electronic mail: Critical social theory and the contextuality of meaning. MIS Quarterly, Minneapolis, 21(2), 145-168.

Overmeer, W. J. A. M., Friedman, V. J., and Lanzara, G. F. (1998). Managing as Design: Business Education for the 21st Century-Reflective Practitioner: Paper \#4. On-line Conference in Memory of Don Schön, and his "The Reflective Practitioner", $23^{\text {rd }}$ February 1998.

Proctor, K. (1993). Tutors professional knowledge of supervision and the implications for supervision practice. In J Calderhead and P Gates.(Eds). Conceptualising Reflection in Teacher Development. London: Falmer Press.

Schon, D A. (1983). The Reflective Practitioner. Averburt Press, Aldershot.

Schon, D A. (1987). Educating the Reflective Practitioner. San Francisco:Jossey Bass Press.

Smyth, J. (1989). Developing and sustaining critical reflection in teacher education. Journal of Teacher Education, 40, (2), pp 2-9.

Van Manen, M. (1995). Researching lived experience. Canada: Althouse Press. University Western Ontario.

Van Manen, M. (2000). Inquiry: Empirical Methods [Online] Available: http://www.phenomenologyonline.com

Whitehead, J (1993). The Growth of Educational Knowledge, Creating Your Own Living Educational Theories. Hyde Publications, Bournemouth.

Whitehead, J. (1998). Developing research-based professionalism through living educational theories. An address to the Educational Studies Association of Ireland, Trinity College, Dublin. [On-line] Available: http://www.bath.ac.uk/6edsajw/writing.shtml (2002, October, 12)

Whitehead, J. (2002). What counts as evidence in self-studies of teacher education practices? [Online] Available: http://www.bath.ac.uk/ edsajw/writing.shtml.(2002), September, 20). 


\section{Macrothink}

International Journal of Education ISSN 1948-5476 2010, Vol. 2, No. 1: E6

Williams, M. Campbell. (2000). Using heuristic self-study to research information systems education. In Proceedings of the International Association of Information Management Conference. Brisbane, Australia

Williams, M. Campbell. (2001). A Self Study of Teaching Reform in a University Information Systems Course: “....it all went wrong...”. Forum Qualitative Sozialforschung / Forum:Qualitative Social Research [On-line Journal], 2(3). [Online] Available: http://www.qualitative-research.net/fqs.htm.

Wong, E. S. (2004). Action Research Philosophy: The Fountain of Living Research. Perth: Centre of Professional Practitioner Resources Publication. ISBN 1-74052111-2

Wong, E. S. (2004). Action Research: The Living Thesis. Perth: Centre of Professional Practitioner Resources Publication. ISBN 1-74052109-9

Wong, E. S., and Williams, C. (2002). Reflective Practitioner Research Applied to information systems, Reality or Illusion? Paper presented at the Third International Web-B Conference 2002.

Yin, R. K. (1994). Case study research design and methods. (2nd Ed.). California: Sage Press. 